\title{
HFE wt Allele
}

National Cancer Institute

\section{Source}

National Cancer Institute. HFE wt Allele. NCI Thesaurus. Code C124876.

Human HFE wild-type allele is located in the vicinity of $6 \mathrm{p} 21.3$ and is approximately $11 \mathrm{~kb}$ in length. This allele, which encodes hereditary hemochromatosis protein, is involved in iron homeostasis. Mutation of the gene is associated with hemochromatosis and microvascular complications of diabetes 7 . 